\title{
Determining the Sediment Quality of Yağlıdere Stream (Giresun)
}

\author{
Arzu Aydın Uncumusaoğlu ${ }^{1 *}$, Cengiz Mutlu², İlhami Kayış² \\ ${ }^{1}$ Department of Environmental Engineering, Giresun University, 28200 Giresun, Turkey \\ ${ }^{2}$ Department of Biology, Faculty of Science and Arts, Giresun University,28200 Giresun, Turkey
}

\section{A R T I C LE IN F O}

Article history:

Received 24 October 2016

Accepted 09 November 2016

Available online, ISSN: $2148-127 \mathrm{X}$

Keywords:

Sediment

Arsenic

Cadmium

Geo-accumulation index

Yağlidere stream

\section{A B S T R A C T}

Sediments in aquatic systems are often contaminated by various pollutants originating from the sources such as industrial and agricultural discharges, municipal wastewater treatment plants, and storm water. These effects lead to the need to develop sediment quality objectives regarding the protection of aquatic ecosystems and human health. In this study, the sediment samples were collected from five sampling sites and then analyzed in order to identify the concentrations of certain metals (As, Se, Ag, Cd, Na, and $\mathrm{K})$, the levels of $\mathrm{pH}$, conductivity, water content (\%) and organic matter (\%) in the Yağlidere Stream. Finally, Geo-accumulation index values calculated based on the estimations regarding the background trace element concentrations suggested the anthropogenic influences in most of the samples. In conclusion, it was observed that $\mathrm{K}$, $\mathrm{Na}$, As, and Se dominantly accumulated in the study area. These metals may have a negative impact on the research area and create an environmental risk.

\section{Yağlıdere Çayı (Giresun) Sediment Kalitesinin Belirlenmesi}

\section{A K A L E B İ L G İ S İ}

Geliş 24 Ekim 2016

Kabul 09 Kasım 2016

Çevrimiçi baskı, ISSN: 2148-127X

\section{Anahtar Kelimeler:}

Sediment

Arsenik

Kadmiyum

Jeoakümülasyon indeks

Yağlıdere

\section{"Sorumlu Yazar:}

E-mail: arzu.a.uncumusaoglu@ gmail.com

\section{Ö Z E T}

Sucul ekosistemlerde sediment endüstriyel ve tarımsal deşarjlar, evsel atıklar, atık su arıtma tesisleri ve yağmur gibi doğa olayları sonrasında çeşitli kirleticiler tarafindan sıklıkla kirletilmektedir. Bu etkilerinden dolayı sucul ekosistem ve insan sağlı̆̆ını korumak için sediment kalitelerinin geliştirilmeye ihtiyacı vardır. Bu çalışmada Yağlıdere Çayı'ndan 5 istasyondan toplanan sediment örneklerinde bazı metallerin (As, Se, Ag, Cd, $\mathrm{Na}, \mathrm{K}) \mathrm{pH}$, elektriksel iletkenlik, (\%) su içeriği ve (\%) organik madde miktarı analiz edilmiştir. Elde edilen veriler ile yerkabuğundaki iz element miktarlarından faydalanılarak Jeoakümülasyon İndeks değeri tahmin edilmiş ve örneklerin çoğunda antropojenik etkinin varlığ belirlenmiştir. Sonuç olarak, çalışma alanında K, Na, As ve Se'nin baskın olarak biriktiği gözlemlenmiştir. Bu metaller Yağlıdere Çayı'nda olumsuz etkiye sahip ve çevresel risk yaratabilir.

\section{Introduction}

Rapid increase in the world's population in recent years, rapid and unplanned urbanization, tourism, failed land planning, and the domestic wastes, petrol, oils, detergents, radioactive wastes, pesticides, artificial and natural agricultural fertilizers, and heavy metals reach of the aquatic media as a result of intense industrial and technological development. The arrival of these pollutants to the water resources disturbs the balance of aquatic systems.

Hence, the aquatic environment, which is a component of ecosystem, has become the most polluted part of the ecosystem since it has been used as the receiver and the removal area for the used water and wastes, when compared to air and soil. Because of the release of untreated or inefficiently treated domestic and industrial wastes into river waters, many organisms living in these waters face with the threat of extinction. Under favor of developing environmental consciousness of today, as well as preventing the release of harmful wastes into the water, also the effects of the food chain and human are investigated (Griscom et al., 2000; Mutlu et al., 2014; Akcay et al., 2003; Kurnaz et al., 2016; Mutlu et al., 2013; Polat and Akkan, 2016; Mutlu and Aydın Uncumusaoglu, 2016). 
The pollutants reach of the aquatic media through point and non-point discharges. Point discharges are the waste water discharges, and waste waters released from industrial sources, while the non-point discharges originate from the regions, where the dangerous wastes are disposed, and also the pollutants that are released accidentally.

Characterization of the point source types is generally easy. But, however, it is very difficult to accurately characterize the non-point discharges because they are the pesticides released from agricultural lands, and the leakages from the contaminated soils and aquatic sediments, atmospheric accumulation, and residential areas. Moreover, in many cases, the discharges originating from the non-point sources are the complex mixtures, and it is very difficult to estimate the timing and amount of the toxic matters and discharges. One of the most complicated issues with the non-point discharges is that variability of toxic characters because of the compounds (Çetinkaya, 2015).

The thickness and structure of sediment layer are closely related to the physical, chemical, geological, and biological phenomena emerging in aquatic systems, and these events are the main reason for the differences among the deep structures. By the origins, the sediments are divided into 3 groups; a) Lithogenic (terrestrial) Sediment consists of river, wind, anthropogenic factors, icecaps, and volcanic inputs, b) Hydrogenic Sediments, and c) Cosmogenic Sediments (Ergül, 2004).

As a result of the transportation of heavy metals, which are among the pollutant materials, into the aquatic media through rivers, erosion, rain, and floodwaters, the concentration in water and sediment layer also increases. Among the sediment pollutants, the pesticides, detergents, heavy metals, and poly-aromatic hydrocarbons (PAH) have the largest share (Atamanalp and Yan1k, 2001; Ribeiro et al., 2005).

The accumulation of the metals in sediments at the surficial waters may vary depending on the particular structure, geochemical features, organic matter characteristics, grain size, and cation transfer capacity. Since the metals, which have significant importance for the biological cycle in aquatic ecosystems, have toxic effects above the certain concentrations, they are among the most important parameters paying attention in sediment quality studies.

The majority of metal pollution accumulates within the waters, and this accumulation may be in the form of dissolution, as well as it may be in the form of precipitation in sediment without dissolving. Metal pollution may be caused by industrial and agricultural wastes, but also any sort of metal released into the atmosphere may also cause this pollution. Metallic materials in atmosphere return to the earth as a result of the cycle, and then reach at the sediment through the streams. In metal pollution, no chemical or biological degradation occurs; a metal compound transforms into another metal compound, but the metallic ion doesn't disappear (Rainbow, 1995).

In this study, it was aimed to determine the concentrations of certain metals (As, Se, $\mathrm{Ag}, \mathrm{Cd}, \mathrm{Na}$, and $\mathrm{K})$ in Yağlidere Stream and also the levels of $\mathrm{pH}$, electrical conductivity, water content $(\%)$, and organic matter (\%), and to reveal the level and sources of sediment pollution by calculating the Geo-Accumulation Index Value.

\section{Materials and Methods}

Collecting the Sediment Samples

The Yağlidere stream is originated from Erimez Mountains and the length of its main branch is $70 \mathrm{~km}$. After it is formed, Yağlidere passes through the towns and sites and poured into the southeastern Black Sea in Espiye Town. Replicate sample for each location along the stream were collected monthly in November 2013 and October 2014 from 5 stations (Figure 1). Sediment samples were collected with Ekman type $(15 \times 15 \times 15 \mathrm{~cm})$ sediment buppies from 3 different points in each station. Sediment samples collected during the study were brought to the laboratory in ice-protected cups and stored at $-21^{\circ} \mathrm{C}$ under laboratory conditions until analysis.

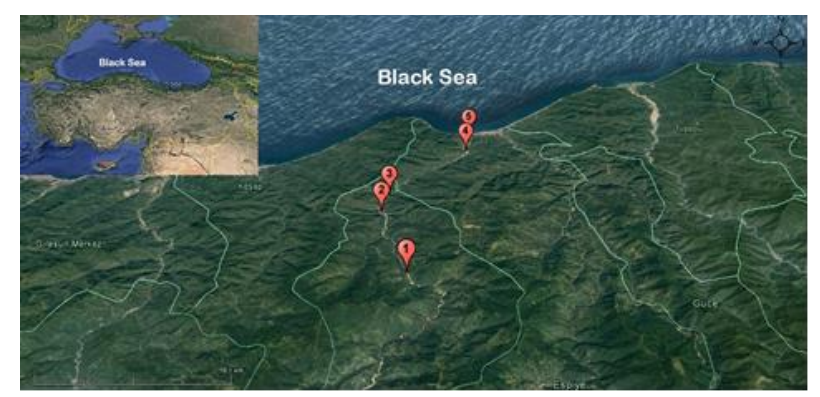

Figure 1 Map of study area with sampling point locations (adapted from Google earth).

\section{Analysis of Sediment Sample}

$\mathrm{pH}$ and Electrical Conductivity Analyses of sediment: the sediment samples weighed in wet form were treated with 1:2.5 pure water. Following the precipitation of wellstirred samples, the $\mathrm{pH}$ and electrical conductivity of supernatant liquid were measured (Landajo et al., 2004).

Amount of Organic Matter (\%) in Sediment; sediment samples were dried at $60^{\circ} \mathrm{C}$, pulverized into $2 \mathrm{~g}$ powder, and then put into porcelain crucibles and kept in crematorium for 2 hours at $550^{\circ} \mathrm{C}$. At the end of this duration, the samples were returned to the room temperature in a desiccator and, following the weighing, then the values were calculated (Egemen, 2000).

Water Content of Sediment (\%); specimens were put into sample containers, dried at $105^{\circ} \mathrm{C}$, and then cooled in desiccator. Using the differences between weights, the percentage of water was calculated (Anonymous, 1995).

Element Analysis of Sediment; for As, Se, Ag, and Cd analyses, the sediment specimens taken from $0-10 \mathrm{~cm}$ layers of the deep sections of stations were sieved using $0.5 \mu \mathrm{m}$ sieve. The sieved samples were left for drying at $102-105^{\circ} \mathrm{C}$ until reaching a constant weight. $1 \mathrm{~g}$ samples were taken from the dried specimen and, after being added to $3 \mathrm{~mL} \mathrm{HCl}$ and $1 \mathrm{~mL} \mathrm{HNO}_{3}$, they kept at room temperature for 24 hours. Then, the samples were taken to the heat table, and treated at $120^{\circ} \mathrm{C}$ unless they clarified. The prepared samples were diluted to $50 \mathrm{~mL}$ by adding deionized water, and prepared for scanning by filtering through blue band filter papers (Anonymous, 1984; Dural and Göksu, 2006). For $\mathrm{Na}$ and $\mathrm{K}$ analyses, the standard method steps in flame photometer were employed.

\section{Statistical Analysis}

The differences between the stations and seasons were analyzed using Variance analysis, One Way ANOVA test, 
and Tukey multiple comparison test. In order to determine the relationship between the sediment parameters, Pearson's correlation was used. All of the statistical calculations were performed using SPSS 17.0

\section{Geo-accumulation Index Analysis (Igeo)}

Proposed by Müller (1969, 1979), the GeoAccumulation Index is now used for determining the level of pollution by comparing the actual metal content to the values obtained before the industrialization. The index was calculated using the formula below;

$$
\operatorname{Igeo}=\log _{2}(C n / B n)
$$

Where $C n$ is the concentration of metals examined in sediment samples and $B n$ is the geochemical back ground concentration of the metal $(n)$. The pollution classes are presented in Table 1 in harmony with the GeoAccumulation Index (Vertacnik et al., 1995; Marvin et al., 2004).

\section{Results and Discussion}

As well as the metal accumulations in sediments through the natural processes cause pollution, the anthropogenic factors became non-ignorable. Besides determining the metals, it is also very important for determining the sediment quality to reveal the organic matter (\%), $\mathrm{pH}$, and water retaining capacity (Leong and Tanner, 1999; Aydın and Sunlu, 2004; Sunlu et al., 2005). In this study, no statistically significant difference was found between the mean values of stations $(\mathrm{P}>0.05)$.

The $\mathrm{pH}$ level in Yağlidere Stream sediment ranged between 6.20 and 8.50. The lowest value was observed in $2^{\text {nd }}$ station in the spring season, while the highest value was observed in $1^{\text {st }}$ station in autumn season. Mean $\mathrm{pH}$ values were found to be $7.50( \pm 0.132)$ in summer, 7.78 $( \pm 0.088)$ in autumn, $7.86( \pm 0.072)$ in winter, and 7.25 $( \pm 0.117)$ in spring seasons. Statistically significant differences were observed between the seasonal mean $\mathrm{pH}$ levels $(\mathrm{P}<0.05) \quad($ Table 2$)$. It is through that the geomorphological structure of the stream's bed may be the reason for high $\mathrm{pH}$ values. These findings are also consistent with the literature data (Akcay et al., 2003; Bakan and Şenel, 2000; Cappuyns and Swennen, 2005).

The mean electrical conductivity (EC) found to be 309 $( \pm 47.983) \mathrm{mS} / \mathrm{cm}$ in summer was determined to be 245 $( \pm 41.796) \mathrm{mS} / \mathrm{cm}$ in autumn, $198( \pm 30.898) \mathrm{mS} / \mathrm{cm}$ in winter, and $234( \pm 43.247) \mathrm{mS} / \mathrm{cm}$ in spring seasons. EC of the sediment of Yağlidere Stream ranged between 60 and $710 \mathrm{mS} / \mathrm{cm}$. The minimum value was observed in $1^{\text {st }}$ station in winter season, while the highest level was observed in $4^{\text {th }}$ station in summer season. It was also determined that the differences between the seasonal mean EC values were not statistically significant $(\mathrm{P}>0.05)$.

Sediment's water content (\%) varied between 12.422 and 41.293; the highest value was observed in $2^{\text {nd }}$ station in the autumn season, while the lowest value was determined in $1^{\text {st }}$ station in autumn season. Seasonal mean values were found to be $20.046( \pm 1.451)$ for summer, $22.750( \pm 1.882)$ for autumn, $23.014( \pm 1.563)$ for winter, and $22.732( \pm 1.963)$ ppm for spring seasons. Besides these values, there was no statistically significant difference between the seasonal mean values $(\mathrm{P}>0.05)$.

The level of combustible organic matter (\%) in sediment varied between 0.250 and 7.600 , while the lowest and highest values were observed in the spring season in $1^{\text {st }}$ and $5^{\text {th }}$ stations, respectively. Mean seasonal values were found to be $1.951( \pm 0.124)$ for summer, $1.912( \pm 0.013)$ for autumn, $2.587( \pm 0.313)$ for the winter, and $3.160( \pm 0.529)$ for spring seasons. When compared to the literature data, the level of combustible organic matter is seen to be low (Bakan and Şenel, 2000). From the aspect of seasonal mean values of combustible organic matter concentration in sediment, the differences were found to be statistically significant $(\mathrm{P}<0.05)$ (Table 3$)$.

Table 1 Geoaccumulation Index Classification

\begin{tabular}{l|cl}
\hline \multicolumn{1}{c|}{ Class } & Value & \multicolumn{1}{c}{ Categorization } \\
\hline Class 0 & Igeo $<0$ & Uncontaminated \\
Class 1 & $0<$ Igeo $<1$ & Uncontaminated to moderately contaminated \\
Class 2 & $1<$ Igeo $<2$ & contaminated \\
Class 3 & $2<$ Igeo $<3$ & Moderately - strongly contaminated \\
Class 4 & $3<$ Igeo $<4$ & Strongly contaminated \\
Class 5 & $4<$ Igeo $<5$ & Strongly - extremely strongly contaminated \\
Class 6 & Igeo $>5$ & Extremely contaminated \\
\hline
\end{tabular}

Table 2 Seasonal Mean, Standard deviation (SD) and range (Minimum- maximum) of pH values in sediment

\begin{tabular}{l|cccccc}
\hline \multicolumn{1}{c}{ Stations } & 1 & 2 & 3 & 4 & 5 & Mean \\
\hline \multirow{2}{*}{ Summer } & $7.33 \pm 0.393$ & $7.50 \pm 0.404$ & $7.57 \pm 0.285$ & $7.47 \pm 0.296$ & $7.63 \pm 0.318$ & $7.50 \pm 0.132^{\mathrm{ab}}$ \\
& $6.80-8.10$ & $6.70-8.00$ & $7.00-7.90$ & $6.90-7.90$ & $7.00-8.00$ & $6.70-8.10$ \\
\hline \multirow{2}{*}{ Autumn } & $8.17 \pm 0.167$ & $7.53 \pm 0.120$ & $7.70 \pm 0.200$ & $7.80 \pm 0.153$ & $7.70 \pm 0.231$ & $7.78 \pm 0.088^{\mathrm{b}}$ \\
& $8.00-8.50$ & $7.30-7.70$ & $7.30-7.90$ & $7.50-8.00$ & $7.30-8.10$ & $7.30-8.50$ \\
\hline \multirow{2}{*}{ Winter } & $8.07 \pm 0.186$ & $8.00 \pm 0.100$ & $7.67 \pm 0.203$ & $7.83 \pm 0.176$ & $7.73 \pm 0.088$ & $7.86 \pm 0.072^{\mathrm{b}}$ \\
& $7,70-8,30$ & $7.80-8.10$ & $7.30-8.00$ & $7.50-8.10$ & $7.60-7.90$ & $7.30-8.30$ \\
\hline \multirow{2}{*}{ Spring } & $7.23 \pm 0.384$ & $6.83 \pm 0.376$ & $7.57 \pm 0.067$ & $7.37 \pm 0.120$ & $7.27 \pm 0.176$ & $7.25 \pm 0.117^{\mathrm{a}}$ \\
& $6.50-7.80$ & $6.20-7.50$ & $7.50-7.70$ & $7.20-7.60$ & $7.00-7.60$ & $6.20-7.80$ \\
\hline
\end{tabular}

${ }^{\mathrm{a}, \mathrm{b}}$ The different letters in same column indicate significant differences $(\mathrm{P}<0.05)$ 
Table 3 Seasonal Mean, Standard deviation (SD) and range (Minimum- maximum) of Organic matter (\%) values in sediment

\begin{tabular}{|c|c|c|c|c|c|c|}
\hline Stations & 1 & 2 & 3 & 4 & 5 & Mean \\
\hline \multirow{2}{*}{ Summer } & $1.563 \pm 0.417$ & $1.783 \pm 0.147$ & $2.090 \pm 0.150$ & $2.263 \pm 0.373$ & $2.053 \pm 0.159$ & $1.951 \pm 0.124^{\mathrm{a}}$ \\
\hline & $0.730-1.980$ & $1.490-1.940$ & $1.940-2.390$ & $1.880-3.010$ & $1.870-2.370$ & $0.730-3.010$ \\
\hline \multirow{2}{*}{ Autumn } & $1.953 \pm 0.022$ & $1.873 \pm 0.029$ & $1.923 \pm 0.015$ & $1.887 \pm 0.050$ & $1.923 \pm 0.015$ & $1.912 \pm 0.013^{\mathrm{a}}$ \\
\hline & $1.910-1.980$ & $1.820-1.920$ & $1.900-1.950$ & $1.790-1.960$ & $1.900-1.950$ & $1.790-1.980$ \\
\hline \multirow{2}{*}{ Winter } & $2.587 \pm 0.632$ & $2.253 \pm 0.298$ & $2.027 \pm 0.087$ & $3.123 \pm 1.188$ & $2.943 \pm 1.054$ & $2.587 \pm 0.313^{3 \mathrm{ab}}$ \\
\hline & $1.950-3.850$ & $1.950-2.850$ & $1.930-2.200$ & $1.930-5.500$ & $1.850-5.050$ & $1.850-5.500$ \\
\hline \multirow{2}{*}{ Spring } & $1.033 \pm 0.434$ & $1.950 \pm 0.506$ & $3.167 \pm 0.689$ & $4.717 \pm 1.120$ & $4.933 \pm 1.353$ & $3.160 \pm 0.529^{b}$ \\
\hline & $0.250-1.750$ & $1.100-2.850$ & $1.800-4.000$ & $3.450-6.950$ & $3.200-7.600$ & $0.250-7.600$ \\
\hline
\end{tabular}

Table 4 Seasonal Mean, Standard deviation (SD) and range (Minimum- maximum) of As values in sediment

\begin{tabular}{l|cccccc}
\hline Stations & 1 & 2 & 3 & 4 & 5 & Mean \\
\hline \multirow{2}{*}{ Summer } & $3.691 \pm 0.638$ & $2.395 \pm 0.080$ & $3.232 \pm 0.302$ & $3.188 \pm 0.972$ & $3.305 \pm 1.403$ & $3.162 \pm 0.332^{\mathrm{a}}$ \\
& $2.867-4.946$ & $2.242-2.514$ & $2.799-3.813$ & $2.095-5.127$ & $1.502-6.068$ & $1.502-6.068$ \\
\hline \multirow{2}{*}{ Autumn } & $4.768 \pm 0.266$ & $3.855 \pm 0.798$ & $3.820 \pm 0.244$ & $6.929 \pm 1.643$ & $4.976 \pm 0.132$ & $4.870 \pm 0.437^{\mathrm{b}}$ \\
& $4.242-5.102$ & $2.872-5.435$ & $3.356-4.182$ & $3.676-8.961$ & $4.824-5.238$ & $2.872-8.961$ \\
\hline \multirow{2}{*}{ Winter } & $4.924 \pm 0.873$ & $4.326 \pm 0.435$ & $3.365 \pm 0.223$ & $4.695 \pm 0.183$ & $4.554 \pm 1.078$ & $4.373 \pm 0.289^{\text {ab }}$ \\
& $3,312-6.309$ & $3.458-4.815$ & $2.921-3.626$ & $4.350-4.972$ & $2.487-6.119$ & $2.487-6.309$ \\
\hline \multirow{2}{*}{ Spring } & $3.827 \pm 0.259$ & $3.405 \pm 0.282$ & $3.022 \pm 0.514$ & $3.678 \pm 0.230$ & $5.829 \pm 0.755$ & $3.952 \pm 0.313^{\text {ab }}$ \\
& $3.539-4.343$ & $2.907-3.882$ & $2.048-3.792$ & $3.406-4.135$ & $4.937-7.331$ & $2.048-7.331$ \\
\hline
\end{tabular}

${ }^{a, b}$ The different letters in same column indicate significant differences $(\mathrm{P}<0.05)$

The arsenic (As) concentration in sediment was found to range between 1.502 and $8.961 \mathrm{ppm}$. The lowest level was observed in $5^{\text {th }}$ station in summer season, while the highest level was recorded at the $4^{\text {th }}$ station in autumn. Seasonal mean As concentrations were calculated to be $3.162( \pm 0.332) \mathrm{ppm}$ for summer, $4.870( \pm 0.437) \mathrm{ppm}$ for autumn, $4.373( \pm 0.289) \mathrm{ppm}$ for winter, and 3.952 $( \pm 0.313) \mathrm{ppm}$ for spring season. Statistically significant differences were observed between the seasonal mean values $(\mathrm{P}<0.05)($ Table 4$)$.

The lowest concentration of Selenium (Se) was observed in the $3^{\text {rd }}$ station in the spring season, while the highest level was recorded at the $4^{\text {th }}$ station in autumn season. Se accumulation in sediment of Yağlidere Stream was found to vary between 0.011 and $0.409 \mathrm{ppm}$. Seasonal mean values in ppm were found to be 0.101 $( \pm 0.015)$ for summer, $0.188( \pm 0.031)$ for autumn, 0.161 $( \pm 0.012)$ for spring, and $0.136( \pm 0,020)$ for winter seasons. There was statistically significant difference between the seasonal mean values $(\mathrm{P}<0.05)$ (Table 5).

The lowest concentration of silver $(\mathrm{Ag})$ was observed at the $3^{\text {rd }}$ station in summer season, while the highest level was recorded in the $2^{\text {nd }}$ station in spring season. $\mathrm{Ag}$ accumulation in the sediment ranged between 0.070 and $0.844 \mathrm{ppm}$. Mean seasonal values expressed in $\mathrm{ppm}$ were found to be $0.100( \pm 0.007)$ summer, $0.170( \pm 0.024)$ for autumn, $0.100( \pm 0.006)$ for the winter, and $0.33( \pm 0.065)$ ppm for spring seasons. There was statistically significant difference between the mean seasonal values $(\mathrm{P}<0.05)$ (Table 6).

The lowest concentration of cadmium $(\mathrm{Cd})$ in sediment of Yağlidere Stream was found to be in the $3^{\text {rd }}$ station in the spring season, while the highest level was observed in the $2^{\text {nd }}$ station in the same season. $\mathrm{Cd}$ accumulation in sediment ranged between 0.009 and $0.473 \mathrm{ppm}$. The seasonal mean values expressed in $\mathrm{ppm}$ were calculated to be $0.132( \pm 0.014)$ for summer, 0.155
$( \pm 0.027)$ for autumn, $0.175( \pm 0.020)$ for the winter, and $0.102( \pm 0.028)$ for the spring season. All of the seasonal mean values were found to be higher than $0.0043 \mathrm{ppm}$ that is the acceptable level of inland water sediments (Angelidis and Aloupi, 2000). The differences between the seasonal mean $\mathrm{Cd}$ concentrations in sediment were found to be statistically non-significant $(\mathrm{P}>0.05)$.

In this study, the sodium (Na) concentration in sediment ranged between 4.90 and $18.10 \mathrm{ppm}$. The lowest $\mathrm{Na}$ concentration was observed in $4^{\text {th }}$ station in winter, while the highest level was recorded in the same station in autumn season. The seasonal mean values expressed in ppm were calculated to be 8.77 ( \pm 0.567$)$ for summer, $8.81( \pm 0.717)$ for autumn, $7.17( \pm 0.499)$ for the winter, and $8.31( \pm 0.753)$ for spring seasons. The differences between the seasonal mean $\mathrm{Na}$ concentrations in sediment were found to be statistically non-significant $(\mathrm{P}>0.05)$.

Having the lowest value in $1^{\text {st }}$ station in summer season, potassium $(\mathrm{K})$ concentration peaked in $5^{\text {th }}$ station in spring season. $\mathrm{K}$ concentration in sediment ranged between 0.30 and $7 \mathrm{ppm}$. The seasonal mean values were found to be $1.69( \pm 0.252) \mathrm{ppm}$ in summer season, 1.69 $( \pm 0.179) \mathrm{ppm}$ in autumn, $2.45( \pm 0.302) \mathrm{ppm}$ in winter, and $2.20( \pm 0.465) \mathrm{ppm}$ in spring. The differences between the seasonal mean $\mathrm{K}$ concentrations in sediment were found to be statistically non-significant $(\mathrm{P}>0.05)$.

When the relationship between parameters were analyzed, the Water Content (\%) showed significant and positive correlation with $\mathrm{OC}, \mathrm{K}$ and $\mathrm{EC}(\mathrm{r}=0.532$, $\mathrm{r}=0.688, \mathrm{r}=0.648 ; \mathrm{P}>0.01)$. The Se concentration showed significant and positive high correlation with as $(\mathrm{r}=0.894$, $\mathrm{P}>0.01$ ), while the EC showed significant and positive correlation with $\mathrm{Na}$ and $\mathrm{K}(\mathrm{r}=0.638, \mathrm{r}=0.653 ; \mathrm{P}>0.01)$, which are responsible for the water mineralization. The $\mathrm{K}$ showed significant and positive correlation with OC $(\mathrm{r}=0$. 582, P>0.01) (Singh et al., 2005; Thuong et al., 2013) (Table 7). 
Table 5 Seasonal Mean, Standard deviation (SD) and range (Minimum- maximum) of Se values in sediment

\begin{tabular}{l|cccccc}
\hline \multicolumn{1}{c}{ Stations } & 1 & 2 & 3 & 4 & 5 & Mean \\
\hline \multirow{2}{*}{ Summer } & $0.146 \pm 0.038$ & $0.071 \pm 0.005$ & $0.083 \pm 0.029$ & $0.098 \pm 0.047$ & $0.106 \pm 0.046$ & $0.101 \pm 0.015^{\mathrm{a}}$ \\
& $0.098-0.222$ & $0.065-0.082$ & $0.053-0.141$ & $0.051-0.191$ & $0.050-0.196$ & $0.050-0.222$ \\
\hline \multirow{2}{*}{ Autumn } & $0.170 \pm 0.039$ & $0.189 \pm 0.105$ & $0.105 \pm 0.016$ & $0.317 \pm 0.091$ & $0.160 \pm 0.020$ & $0.188 \pm 0.031^{\mathrm{b}}$ \\
& $0.103-0.237$ & $0.049-0.395$ & $0.074-0.126$ & $0.135-0.409$ & $0.122-0.192$ & $0.049-0.409$ \\
\hline \multirow{2}{*}{ Winter } & $0.188 \pm 0.036$ & $0.148 \pm 0.028$ & $0.122 \pm 0.008$ & $0.181 \pm 0.020$ & $0.169 \pm 0.036$ & $0.161 \pm 0.012^{\mathrm{ab}}$ \\
& $0.130-0.254$ & $0.106-0.200$ & $0.109-0.136$ & $0.142-0.206$ & $0.096-0.207$ & $0.096-0.254$ \\
\hline \multirow{2}{*}{ Spring } & $0.135 \pm 0.033$ & $0.105 \pm 0.022$ & $0.093 \pm 0.044$ & $0.122 \pm 0.011$ & $0.224 \pm 0.067$ & $0.136 \pm 0.02^{\mathrm{ab}}$ \\
& $0.078-0.193$ & $0.062-0.136$ & $0.011-0.161$ & $0.107-0.144$ & $0.141-0.357$ & $0.011-0.357$ \\
\hline
\end{tabular}

${ }^{\mathrm{a}, \mathrm{b}}$ The different letters in same column indicate significant differences $(\mathrm{P}<0.05)$

Table 6 Seasonal Mean, Standard deviation (SD) and range (Minimum- maximum) of Ag values in sediment

\begin{tabular}{l|cccccc}
\multicolumn{1}{c}{ Stations } & 1 & 2 & 3 & 4 & 5 & Mean \\
\hline \multirow{2}{*}{ Summer } & $0.114 \pm 0.022$ & $0.088 \pm 0.001$ & $0.095 \pm 0.012$ & $0.099 \pm 0.019$ & $0.103 \pm 0.021$ & $0.100 \pm 0.007^{\mathrm{a}}$ \\
& $0.092-0.157$ & $0.085-0.089$ & $0.070-0.110$ & $0.078-0.138$ & $0.076-0.145$ & $0.070-0.157$ \\
\hline \multirow{2}{*}{ Autumn } & $0.147 \pm 0.034$ & $0.124 \pm 0.032$ & $0.148 \pm 0.060$ & $0.304 \pm 0.060$ & $0.127 \pm 0.005$ & $0.170^{\mathrm{a}} \pm 0.024^{\mathrm{a}}$ \\
& $0.112-0.214$ & $0.084-0.187$ & $0.081-0.268$ & $0.184-0.368$ & $0.119-0.137$ & $0.081-0.368$ \\
\hline \multirow{2}{*}{ Winter } & $0.110 \pm 0.019$ & $0.093 \pm 0.012$ & $0.089 \pm 0.005$ & $0.104 \pm 0.009$ & $0.103 \pm 0.018$ & $0.100 \pm 0.006^{\mathrm{a}}$ \\
& $0.091-0.148$ & $0.080-0.117$ & $0.082-0.098$ & $0.087-0.115$ & $0.079-0.138$ & $0.079-0.148$ \\
\hline \multirow{2}{*}{ Spring } & $0.392 \pm 0.213$ & $0.400 \pm 0.228$ & $0.270 \pm 0.152$ & $0.274 \pm 0.093$ & $0.327 \pm 0.108$ & $0.333 \pm 0.065^{\mathrm{b}}$ \\
& $0.117-0.812$ & $0.084-0.844$ & $0.082-0.572$ & $0.090-0.382$ & $0.113-0.464$ & $0.082-0.844$ \\
\hline
\end{tabular}

${ }^{\mathrm{a}, \mathrm{b}}$ The different letters in same column indicate significant differences $(\mathrm{P}<0.05)$

Table 7 Relations between parameters matrix (Pearson correlation)

\begin{tabular}{|c|c|c|c|c|c|c|c|c|c|c|}
\hline $\mathrm{P}$ & $\begin{array}{l}\text { Organic } \\
\text { Matter }\end{array}$ & $\begin{array}{c}\text { Water } \\
\text { Content }\end{array}$ & As & $\mathrm{Se}$ & $\mathrm{Ag}$ & $\mathrm{Cd}$ & $\mathrm{EC}$ & $\mathrm{Na}$ & K & $\mathrm{pH}$ \\
\hline $\mathrm{OM}$ & 1 & & & & & & & & & \\
\hline WC & $0.532 * *$ & 1 & & & & & & & & \\
\hline As & -0.053 & 0.061 & 1 & & & & & & & \\
\hline $\mathrm{Se}$ & -0.041 & 0.036 & $0.894^{* *}$ & 1 & & & & & & \\
\hline $\mathrm{Ag}$ & 0.045 & -0.025 & 0.147 & 0.089 & 1 & & & & & \\
\hline $\mathrm{Cd}$ & -0.126 & -0.124 & 0,206 & 0.224 & $-0.313^{*}$ & 1 & & & & \\
\hline $\mathrm{EC}$ & $0.375^{\text {** }}$ & $0.648 * *$ & -0.039 & -0.041 & -0.033 & -0.068 & 1 & & & \\
\hline $\mathrm{Na}$ & 0.123 & $0.326 *$ & 0.163 & 0.133 & -0.008 & -0.122 & $0.638^{* *}$ & 1 & & \\
\hline $\mathrm{K}$ & $0.582^{* *}$ & $0.688 * *$ & 0,114 & 0.089 & 0.063 & -0.027 & $0.653^{\text {** }}$ & $0.388^{* *}$ & 1 & \\
\hline $\mathrm{pH}$ & -0.122 & -0.051 & 0.249 & 0.179 & $-0.455^{* *}$ & 0.078 & -0.175 & -0.133 & -0.075 & 1 \\
\hline
\end{tabular}

P: Parameters, $* * \mathrm{P}<0.01, * \mathrm{P}<0.05$

Since the streams have the character of continuous receiver media, they are the natural resources that are seriously open to the pollutants. The pollutions in any environment are not limited to those regions, but these pollutants are transported by the water streams. Especially the accumulation trend of toxic pollutants in an ecosystem poses a significant risk to the lives of organisms living in that system. Thus, determining the source of pollutants is very important for maintaining the balance of streams that are very sensitive. In order to verify that the metal accumulation in the sediment originates from the anthropogenic activities, certain quality indices such as Geo-Accumulation Index are employed. The GeoAccumulation Index values calculated for 6 elements in 60 sediment specimens collected in our study are presented in Table 8 .

The Igeo values calculated using the specimens taken from the sediment of Yağlidere Stream are as follows; As: 1.17 (0-2.5), Se: 1.69 (0-5.2), Ag: -1.55 (-4.2 - -0.6), Cd: 0.79 (-1.2-4.5), Na: 9.65 (8.5-10.4), and K: 13.35 (11.315.9). It was determined that, except for $\mathrm{Ag}$, there was an inclination towards the pollution for all of elements, and that $\mathrm{Na}$ and $\mathrm{K}$ parameters indicated severe pollution (Asa and Rath, 2014).
In other study that has been carried out in order to determine the heavy metal pollution at the points, where the some streams in Giresun coast are discharged to the sea, it has been reported that the mean seasonal cadmium (Cd) concentrations of Aksu, Batlama, Boğacık, Camiyalısı and Güre Streams were found to be 0.305 , $0.433,0.253,0.129,0.300$ for winter season, 0.423, $0.875,3.172,5.113,2.896$ for spring season, $0.553,0.552$, $0.515,0.790,1.198$ for autumn season, and $0.654,0.589$, $0.698,0.800,1.059 \mathrm{ppm}$ for summer season (Türkmen and Akbulut, 2015). Cd element, which is also examined in our study, has been determined to be at its highest point in Camiyalısı Stream only in summer season. This parameter's values are lower in other seasons and stations.

In study of Bakan and Şenel (2000) on Mert River (Samsun), they have reported sediment $\mathrm{pH}$ to be $6.8-7.65$ and the level of combustible organic matter to be $5.61 \%$ (Bakan and Şenel, 2000). In study of Ünal (2010) on sediment of Yeşilırmak River, the mean values were reported to be as follows (min., max.) in $\mu \mathrm{g} / \mathrm{g}$; Fe: 10973566, Zn: 26.5 - 45.5, Cu: 28.6 - 38.7, Pb: 5.2 - 17.3, Mn: 294- 446, Ni:70.3 - 7.2, Cd: lower than measurable limit - 
0.55 (Ünal, 2010). In study of Gümüşler Stream, the mean values were reported to be Cd:4.4 ppm, As: $268.6 \mathrm{ppm}$, Ag:4.4 ppm, Na:2627.6 ppm, and K:15584 ppm (Yalçın et al., 2007). The concentrations of elements in sediment of Lot River (France) have been reported to be as follows; Cu: 97.7-26.9 ppm, Zn: 134-4430 ppm, Cd: 0.81-125 ppm, Pb:43.6-523 ppm (Audry et al., 2004).

As a result of sediment quality index analysis of Tiaozi River (China) according to Geo-Accumulation Index, the classes of 3 regions examined have been reported to vary between Class 0 and Class 1 (Dong et al., 2015). Igeo index result of Lich River (Vietnam) have indicated the quality to be Class 0 in terms of $\mathrm{Mn}, \mathrm{Fe}, \mathrm{Ni}$ and $\mathrm{Cr}$, Class 1 in terms of $\mathrm{Cu}$, Class 2 in terms of $\mathrm{Pb}$ and $\mathrm{Zn}$, Class 3 in terms of As, and Class 4 in terms of $\mathrm{Cd}$
(Thuong et al., 2013). The Igeo vales determined in Kavak Delta were found to be positive for $\mathrm{Cd}, \mathrm{Li}, \mathrm{Ni}, \mathrm{Pb}$ and $\mathrm{Se}$ and negative for $\mathrm{Ba}, \mathrm{Cr}, \mathrm{Cu}, \mathrm{Sr}$ and $\mathrm{Zn}$. In same study, it has also been reported that classes of $\mathrm{Cd}$ and $\mathrm{Se}$ were Class 2 and those of $\mathrm{Li}, \mathrm{Ni}$ and $\mathrm{Pb}$ were Class 1 (Sungur and Özcan, 2014).

According to the results of Geo-Accumulation Index analyses implemented in this study, As was found to vary between Class 1 and 3, Se to be observed in all classes, Ag to be Class $0, \mathrm{Cd}$ to be Class 0 and 5 , and $\mathrm{Na}$ and $\mathrm{K}$ to be Class 6 . Highest Igeo values were found to be in $5^{\text {th }}$ station in June for As (2.50), in $3^{\text {rd }}$ station in March for Se (5.20), in $3^{\text {rd }}$ station in May for $\mathrm{Cd} 4.50$, in $4^{\text {th }}$ station in January for $\mathrm{Na}(10.4)$, and in $1^{\text {st }}$ station in June for $\mathrm{K}$ (15.9).

Table 8 Elements of Geo-accumulation Index Analysis ( Igeo )

\begin{tabular}{|c|c|c|c|c|c|c|c|c|c|c|c|c|c|c|c|}
\hline & \multicolumn{5}{|c|}{ June } & \multicolumn{5}{|c|}{ July } & \multicolumn{5}{|c|}{ August } \\
\hline & 1 & 2 & 3 & 4 & 5 & 1 & 2 & 3 & 4 & 5 & 1 & 2 & 3 & 4 & 5 \\
\hline As & 1.4 & 1.8 & 1.2 & 2.0 & 2.5 & 1.6 & 1.8 & 1.5 & 1.9 & 1.9 & 0.8 & 2.0 & 1.6 & 0.8 & 0.5 \\
\hline $\mathrm{Se}$ & 2.0 & 2.3 & 1.5 & 3.0 & 3.0 & 1.7 & 2.6 & 2.8 & 3.0 & 2.5 & 0.9 & 2.6 & 2.9 & 1.1 & 1.0 \\
\hline $\mathrm{Ag}$ & -1.0 & -0.9 & -1.2 & -0.8 & -0.9 & -1.0 & -0.9 & -0.6 & -0.7 & -0.7 & -1.7 & -0.9 & -1.2 & -1.6 & -1.6 \\
\hline $\mathrm{Cd}$ & 0.7 & 0.5 & 0.5 & 0.6 & 0.9 & 0.3 & 0.3 & 0.2 & 0.4 & 0.5 & -0.4 & 2.0 & 1.2 & 0.9 & 2.5 \\
\hline $\mathrm{Na}$ & 9.4 & 9.8 & 9.3 & 9.0 & 9.4 & 10.2 & 9.8 & 10.0 & 9.0 & 9.4 & 10.0 & 9.7 & 9.7 & 9.3 & 9.2 \\
\hline \multirow[t]{3}{*}{$\mathrm{K}$} & 15.9 & 14.0 & 12.9 & 12.2 & 12.9 & 14.6 & 13.3 & 13.7 & 12.5 & 13.2 & 14.9 & 14.3 & 13.7 & 13.4 & 13.0 \\
\hline & \multicolumn{5}{|c|}{ September } & \multicolumn{5}{|c|}{ October } & \multicolumn{5}{|c|}{ November } \\
\hline & 1 & 2 & 3 & 4 & 5 & 1 & 2 & 3 & 4 & 5 & 1 & 2 & 3 & 4 & 5 \\
\hline As & 0.8 & 1.6 & 1.1 & 0.0 & 0.8 & 0.8 & 0.7 & 1.1 & 0.1 & 0.8 & 1.0 & 1.4 & 1.4 & 1.2 & 0.7 \\
\hline $\mathrm{Se}$ & 1.2 & 3.0 & 2.4 & 0.0 & 1.7 & 0.8 & 0.0 & 1.7 & 0.0 & 1.3 & 2.0 & 1.7 & 1.8 & 1.6 & 1.1 \\
\hline $\mathrm{Ag}$ & -1.3 & -0.8 & -0.8 & -3.0 & -1.6 & -1.3 & -1.1 & -1.0 & -2.0 & -1.3 & -2.2 & -2.0 & -2.5 & -3.0 & -1.4 \\
\hline $\mathrm{Cd}$ & -0.8 & 0.8 & 0.8 & -0.2 & 0.9 & 0.3 & -0.2 & 1.1 & 0.8 & 1.9 & 0.8 & 0.6 & 2.0 & 1.6 & -1.0 \\
\hline $\mathrm{Na}$ & 10.0 & 9.7 & 9.6 & 8.5 & 9.3 & 9.9 & 9.6 & 9.8 & 9.5 & 9.6 & 9.5 & 9.3 & 9.7 & 9.7 & 9.5 \\
\hline \multirow[t]{3}{*}{$\mathrm{K}$} & 13.7 & 13.2 & 14.4 & 12.4 & 12.9 & 15.1 & 13.4 & 13.6 & 13.5 & 13.1 & 14.3 & 13.3 & 12.8 & 13.2 & 13.3 \\
\hline & \multicolumn{5}{|c|}{ December } & \multicolumn{5}{|c|}{ January } & \multicolumn{5}{|c|}{ February } \\
\hline & 1 & 2 & 3 & 4 & 5 & 1 & 2 & 3 & 4 & 5 & 1 & 2 & 3 & 4 & 5 \\
\hline As & 0.5 & 0.8 & 1.3 & 1.0 & 0.5 & 0.8 & 0.9 & 1.3 & 0.9 & 0.8 & 1.4 & 1.3 & 1.6 & 0.8 & 1.8 \\
\hline $\mathrm{Se}$ & 0.7 & 1.6 & 1.6 & 1.5 & 0.9 & 1.2 & 1.0 & 1.9 & 1.0 & 1.0 & 1.6 & 1.9 & 1.7 & 1.0 & 2.1 \\
\hline $\mathrm{Ag}$ & -1.7 & -0.8 & -0.9 & -0.9 & -1.6 & -1.0 & -1.3 & -0.8 & -1.3 & -1.0 & -1.0 & -0.8 & -1.1 & -1.2 & -0.8 \\
\hline $\mathrm{Cd}$ & 1.0 & 0.1 & 0.6 & 0.4 & -0.3 & -0.4 & 0.7 & 0.6 & 0.8 & -0.4 & -0.9 & 0.3 & 0.7 & 0.4 & 0.9 \\
\hline $\mathrm{Na}$ & 10.1 & 10.0 & 9.7 & 9.6 & 9.3 & 10.2 & 10.2 & 10.2 & 10.4 & 9.5 & 10.0 & 9.7 & 9.9 & 9.6 & 9.1 \\
\hline \multirow[t]{3}{*}{$\mathrm{K}$} & 13.7 & 13.6 & 12.6 & 13.0 & 12.1 & 13.5 & 13.3 & 13.3 & 12.6 & 11.7 & 13.0 & 12.9 & 13.4 & 13.2 & 12.1 \\
\hline & \multicolumn{5}{|c|}{ March } & \multicolumn{5}{|c|}{ April } & \multicolumn{5}{|c|}{ May } \\
\hline & 1 & 2 & 3 & 4 & 5 & 1 & 2 & 3 & 4 & 5 & 1 & 2 & 3 & 4 & 5 \\
\hline As & 1.3 & 1.6 & 2.1 & 1.1 & 0.2 & 1.0 & 1.2 & 1.4 & 1.3 & 0.7 & 1.3 & 1.3 & 1.2 & 1.3 & 0.8 \\
\hline $\mathrm{Se}$ & 1.6 & 1,8 & 5.2 & 1.5 & 0.2 & 1.1 & 1.6 & 1.9 & 1.9 & 1.5 & 2.4 & 2.7 & 1.3 & 1.8 & 1.2 \\
\hline $\mathrm{Ag}$ & -2.4 & -2.5 & -1.7 & -3.0 & -3.3 & -1.3 & -0.8 & -0.8 & -1.0 & -1.3 & -4.1 & -4.2 & -3.6 & -2.9 & -3.1 \\
\hline $\mathrm{Cd}$ & 2.0 & 1.5 & 3.5 & 1.9 & 1.5 & 0.5 & $-1,2$ & 0.7 & 1.3 & 0.9 & 0.9 & 1.6 & 4.5 & 1.9 & 0.9 \\
\hline $\mathrm{Na}$ & 8.6 & 9.9 & 9.6 & 9.2 & 10.0 & 10.1 & 9.9 & 9.7 & 9.7 & 9.1 & 10.1 & 10.3 & 9.6 & 9.5 & 9.5 \\
\hline $\mathrm{K}$ & 13.4 & 14.3 & 14.9 & 12.5 & 13.3 & 13.4 & 14.1 & 14.4 & 12.8 & 12.5 & 14.1 & 14.6 & 12.9 & 11.8 & 11.3 \\
\hline
\end{tabular}

\section{Conclusion}

It was determined that the accumulation in this streambed, where the industrial activities are not very intense, was at considerable level. Moreover, according to the index analysis results, it was also revealed that the streambed is very sensitive to the anthropogenic activities. Furthermore, it was concluded that the seasonal changes influenced some of the parameters in this streambed. Besides the fact that intense HPP (Hydroelectric Power Plan) activity alongside this stream draws attention, it was also observed that there were discharges of point wastes especially from the district center of Yağlidere. Throughout the sampling period, significant decreases were observed in flowrate of stream, and it was also observed that the HPPs in the region were responsible for this variation. As another reason for the metal accumulation in stream sediment, because of the geomorphological characteristics of the region, natural landslides and those caused from anthropogenic factors were frequently seen in this region during the study. It was revealed that, except for $\mathrm{Ag}$, pollution trend was observed for all of elements and $\mathrm{Na}$ and $\mathrm{K}$ posed the risk of severe pollution.

In conclusion, it was revealed that the streambed of Yağlıdere Stream is very sensitive to anthropogenic activities, as well as it was projected that the metal accumulation in sediment might threaten the aquatic life unless the discharge points of businesses alongside the stream towards Yağlidere district center and Espiye district will be taken under regular control. 


\section{References}

Akcay H, Oguz A, Karapire C. 2003. Study of heavy metal pollution and speciation in Buyuk Menderes and Gediz River sediments. Water Research, 37 (4): 813-822.

Angelidis MO, Aloupi M. 2000. Geochemical study of coastal sediments influenced by river-transported pollution: Southern Evoikos Gulf, Greece. Marine Pollution Bulletin, 40: 77-82.

Anonymous. 1984. Determination of total cadmium, zinc, lead and copper in selected marine organisms by flameless atomic absorption spectrophotometry united nations environment programme. Methods for Marine Pollution Studies No:11, Revision 1, Geneva.

Anonymous. 1995. Standard methods for the examination of water and wastewater, 19 th Ed. APHA, AWWA, WPCF, Washington.

Asa SC, Rath P. 2014. Sediment quality assesment through Geaccumulation index of Brahmani River, estuarine system, Odisha, India. International Journal of Energy, Sustainability and Environmental Engineering, 1(1): 13-15.

Atamanalp M, Yanık T. 2001. Pestisitlerin Cyprinidae'lere toksik etkileri. E. Ü. Su Ürünleri Dergisi, 18: 555-563.

Audry S, Schafer J, Blanc G, Jouanneau JM. 2004. Fifty-year sedimentary record of heavy metal pollution $(\mathrm{Cd}, \mathrm{Zn}, \mathrm{Cu}$, $\mathrm{Pb}$ ) in the Lot River reservoirs (France). Environmental Pollution, 132: 413-426.

Aydin A, Sunlu U. 2004. The investigation of carbon and burnable substances levels which are found in the southern Aegean Sea sediments. E.U. Journal of Fisheries \& Aquatic Sciences. 21 (3-4):229-334.

Bakan G, Şenel B. 2000. Samsun Mert Irmağ1-Karadeniz deşarjında yüzey sediman (dip çamur) ve su kalitesi araştırması, Turk. J. Engin. Environ. Sci., 24,135-141.

Cappuyns V, Swennen R. 2005. Kinetics of element release during combined oxidation and $\mathrm{pH}$ stat leaching of anoxic river sediments Applied Geochemistry, 20(6):1169-1179.

Çetinkaya M. 2015. Co (II), Cr (III) ve Ni (II) metal iyonlarının sulu ortamlarda Mucor pusillus (Lindt., 1886) immobilize edilmiş aktif $\mathrm{Al}_{2} \mathrm{O}_{3}$ biyokompozitte zenginleştirilme şartlarının araştırılması ve alevli AAS ile tayini. Nevşehir Hacı Bektaş Veli Üniversitesi, Fen Bilimleri Enstitüsü, Nevşehir.

Dong D, Liu X, Guo Z, Hua X, Su Y, Liang, D. 2015. Seasonal and spatial variations of heavy metal pollution in water and sediments of China's Tiaozi River. Pol. J. Environ. Stud. 24(6): 2371-2379.

Dural M, Göksu MZL. 2006. Çamlık Lagünü (Karataş, Adana), seston, bentoz ve sedimentinde mevsimsel ağır metal değişimi, E. Ü. Su Ürünleri Dergisi, 23(1): 65-69.

Egemen Ö. 2000. Çevre ve su kirliliği. E. Ü. Su Ürünleri Fak., Yayın No 42, 116, Bornova, İzmir.

Ergül HA. 2004. Karadeniz'in Trabzon yöresinde Oksik Zon'da sedimentasyon yapan materyalin bazı ağır metal, radyonüklid, organik karbon ve klorofil-a düzeylerinin araştırılması. Karadeniz Teknik Üniversitesi, Fen Bil. Ens. Doktora Tezi, Trabzon.

Griscom S, Fisher NC, Luoma SN. 2000. Geochemical influences on assimilation of sediment-bound metals inclams and mussels. Environ., Sci., Technol., 34: 91-99.

Kurnaz A, Mutlu E, Aydin Uncumusaoğlu A. (2016). determination of water quality parameters and heavy metal content in surface water of Çiğdem Pond (Kastamonu/Turkey) Turkish Journal of Agriculture - Food Science and Technology, 4(10): 907-913.
Landajo A, Arana G, Diego AD, Etxebarria N, Zuloaga O, Amouroux D. 2004. Analysis of heavy metal distribution in superficial estuarine sediments (Estuary of Bilbao, Basque Country) by open-focused microwave-assisted extraction and ICP-OES. Chemosphere, 56: 1033-1041.

Leong LS, Tanner PA. 1999. Comparison of methods for determination of organic carbon in marine sediment, Marine Pollution Bulletin, 38(10): 875-879.

Marvin C, Grapentine L, Painter S. 2004. Application of a sediment quality index to the lower laurentian great lakes, Environmental Monitoring and Assessment, 91, 1-16.

Muller G. 1969. Index of geo-accumulation in sediments of the Rhine River, Geojournal, 2: 108-118.

Mutlu E, Yanik T, Demir T. 2013. Horohon Deresi (HafikSivas) su kalitesi özelliklerinin aylık değişimleri. Alınteri Zirai Bilimleri Dergisi 25(B):45-57.

Mutlu E, Kutlu B, Demir T, Yanık T, Sutan NA. 2014. The evaluation of water quality parameters of Beydilli River (Hafik-Sivas). Journal of Selçuk University Natural and Applied Science. 40-52.

Mutlu E, Aydın Uncumusaoğlu A. 2016. Physicochemical analysis of water quality of Brook Kuruçay. Turkish Journal of Agriculture - Food Science and Technology, 4(11): 991998.

Müller G. 1979. Schwermetalle in den sedimenten des Rheins Veranderungen seit 1971, Umschau, 79(24): 778-783.

Rainbow PS.1995. Biomonitoring of heavy metal availability in the marine environment, Marine Pollution Bulletin, 31:183192

Ribeiro CAO, Vollaire Y, Sanchez-Chardi A, Roche H. 2005. Bioaccumulation and the effects of organochlorine pesticides, PAH and heavy metals in the eel (Anguilla anguilla), at the Camargue Nature Reserve, France. Aquatic Toxicology, 74(1):53-69.

Singh KP, Malik A, Sinha S. 2005. Water quality assessment and apportionment of pollution sources of Gomti River (India) using multivariate statistical techniques, a case study, Analytica Chimica Acta, 538 (1-2): 355-374.

Sungur A, Özcan H. 2014. Chemometric and geochemical study of the heavy metal accumulation in the soils of a salt marsh area (Kavak Delta, NW Turkey). J Soils Sediments, 15:323331.

Sunlu U, Aydın A, Özçetin NE. 2005. The investigation of carbon and burnable substances levels in sediments from the northern Aegean Sea. E.U. Journal of Fisheries \& Aquatic Sciences. 22 (3-4):263-268.

Thuong NT, Yoneda M, Ikegami M, Takakuro M. 2013. Source discrimination of heavy metals in sediment and water of Lich River in Hanoi City using multivariate statistical approaches. Environ Monit Assess, 185:8065-8075.

Türkmen A, Akbulut S. 2015. Giresun sahilindeki bazı derelerin denize deşarj olduğu noktalardaki su ve sedimentte ağır metal kirliliği. Turkish Journal of Agriculture - Food Science and Technology, 3(9): 707-714

Polat N, Akkan T. 2016. Assessment of heavy metal and detergent pollution in Giresun coastal zone, Turkey Fresenius Environmental Bulletin, 25(8): 2884-2890

Ünal ÖF. 2010. Yeşilırmak Nehri'nden toplanan balık ve sediment örneklerinde eser element tayini. Gazi Osman Paşa Üniversitesi, Yüksek Lisans Tezi,Tokat.

Vertacnik A, Prohic E, Kozar S, Juracic M. 1995. Behavior of some trace elements in alluvial sediments, Zagreb waterwell field area, Croatia, Water Research, 29: 237-46.

Yalçın MG, Narin İ, Soylak M. 2007. Multivariate analysis of heavy metal contents of sediments from Gümüşler Creek, Niğde, Turkey. Environ Geol, 54: 1155-1163. 